\title{
NUMERICAL ANALYSIS OF DEFLECTIONS OF MULTI-LAYERED BEAMS
}

\author{
Tadeusz BILIŃSKI, Tomasz SOCHA ${ }^{1}$ \\ University of Zielona Gora, Institute of Building Engineering, Poland
}

\begin{abstract}
The paper concerns the rheological bending problem of wooden beams reinforced with embedded composite bars. A theoretical model of the behaviour of a multi-layered beam is presented. The component materials of this beam are described with equations for the linear viscoelastic five-parameter rheological model. Two numerical analysis methods for the long-term response of wood structures are presented. The first method has been developed with SCILAB software. The second one has been developed with the finite element calculation software ABAQUS and user subroutine UMAT. Laboratory investigations were conducted on sample beams of natural dimensions in order to validate the proposed theoretical model and verify numerical simulations. Good agreement between experimental measurements and numerical results is observed.
\end{abstract}

Keywords: ABAQUS, creep, composite materials, FEM, multi-layered structures, reinforcing of structures, rheology, wood

\section{INTRODUCTION}

This paper concerns the results of experimental tests, theoretical and numerical models of rheological bending problem of wooden beams reinforced with embedded composite bars. A theoretical model of these beams is presented, in which the rheological properties of the component materials have been described with the constitutive relations of linear viscoelasticity in the form of the five-parameter model. We have adopted the Bernoulli hypothesis of plane cross-sections and assumed perfect bond between the layers without slip. The

\footnotetext{
${ }^{1}$ Corresponding author: University of Zielona Gora, Institute of Building Engineering, Szafrana st 1, 65-516 Zielona Gora, Poland, e-mail: t.socha@ib.uz.zgora.pl, tel.+48683282271
} 
equation of motion for the beam displacement is derived by means of operator calculus.

The first numerical model was made in ABAQUS and INTEL FORTRAN COMPILER. The second one based on the finite element method and a Lagrange functional written for the viscoelastic multi-layered beam and obtained by means of our own computer application, which was written in the environment of SCILAB.

Laboratory investigations were conducted on sample beams of natural dimensions in order to validate the proposed theoretical model and verify numerical simulations. Good agreement between our experimental measurements and numerical results is observed.

\section{LABORATORY TESTS}

Long-term experimental investigations of layered beams were conducted at the laboratory in the Institute of Building Engineering at the University of Zielona Góra. The multi-layered beams of natural dimensions made of wood, polyester glass composite bars and epoxy adhesive, were examined in the four-point bending test (Fig. 2).

With the aim of comparison, additional tests were carried out on wooden beams of homogenous cross-section with the identical geometrical characteristics as the layered beam's cross-section. The cross-sections of the beams and their geometrical characteristics are displayed in Fig. 1, wherein the symbols denote:

- $A^{D}, A^{K}, A^{L}, A^{P} \quad$ - areas of cross-section,

- $E_{0}^{D}, E_{0}^{K}, E_{0}^{L}, E_{0}^{P} \quad$ - elastic moduli,

- $I^{L}, I^{Z} \quad$ - the moment of inertia of cross-sectional area,

- $W^{L}, W_{g}^{Z}, W_{d}^{Z} \quad$ - section moduli,

- $D, K, L, P, Z \quad$ - index of materials: wood, adhesive, homogeneous beam, composite bar, reinforced beam.

Up to the point of stress value being equal appr. $30 \%$ of failure load, the wood may be treated as linear viscoelastic medium [5]. Therefore, in experiments the equal stress $30 \% \bar{F}_{n}^{L}$ was adopted, where $\bar{F}_{n}^{L}$ is the average force destroying the homogenous beam, marked earlier in tests on short-term loads. The duration of the load equalled 100 days. Six beams of each type (LS and ZS) were subjected to the test and the mean values of the results were calculated. 
a)

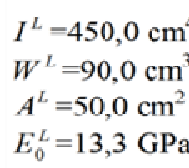

b)

$I^{Z}=447,0 \mathrm{~cm}^{4}$

$W_{\mathrm{s}}^{Z}=87,0 \mathrm{~cm}^{3}$

$W_{d}^{Z}=92,0 \mathrm{~cm}^{3}$

$A^{D}=48,0 \mathrm{~cm}^{2}$

$A^{K}=1,0 \mathrm{~cm}^{2}$

$A^{P}=1,0 \mathrm{~cm}^{2}$

$E_{0}^{D}=13,8 \mathrm{GPa}$

$E_{0}^{K}=2,4 \mathrm{GPa}$

$E_{\mathrm{o}}^{P}=45,0 \mathrm{GPa}$

epoxy glue

composite bar

$\phi 0,8 \mathrm{~cm}$

Fig. 1. Cross-sections of the tested beams: a) homogeneous wooden cross-section, LS, b) cross-section with embedded composite reinforcement, ZS

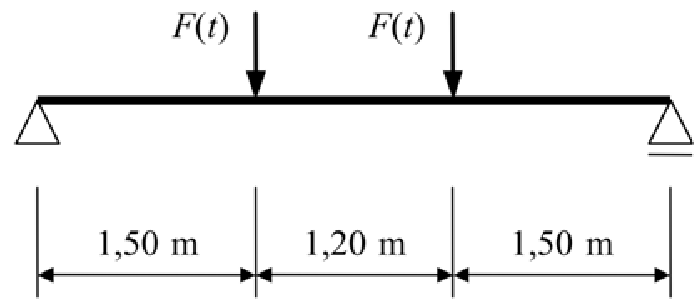

Fig. 2. General view of LS and ZS beams

\section{THEORETICAL MODEL}

A typical multilayer beam is illustrated in Fig. 1.

The following assumptions have been made $[1,3]$ :

1. A cross section of a beam is symmetrical with respect to the vertical axis $z$.

2. A beam is composed of layers made of linear viscoelastic materials exhibiting the same rheological properties in tension and compression.

3. Planar cross-sections remain planar before and after bending (the Bernoulli hypothesis).

4. The layers are perfectly joined without slip.

5. Temperature and moisture conditions are constant in time. 


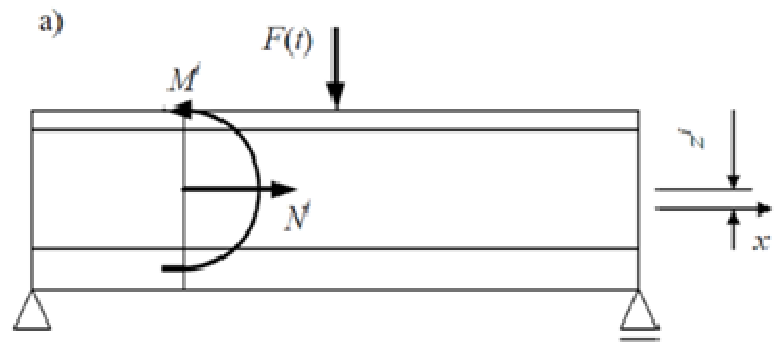

b)

Fig. 3. A multi-layered beam: a) internal forces in ith layer,

b) a cross-section of the beam

Using the above assumptions we can calculate:

- the time changeable distance from the neutral axis

$$
\sum_{i=1}^{n} E^{i} \cdot S^{i}=0
$$

- the total bending moment in cross-section

$$
M=\sum_{i=1}^{n} M^{i}=\sum_{i=1}^{n} E^{i} * d k \cdot I^{i}
$$

- the normal stresses in an ith layer

$$
\sigma^{i}=E^{i} * d k \cdot z^{i}
$$

where:

$S^{i}$ - the static moment of cross-sectional area $A^{i}$ of ith layer,

$I^{i}$ - the moment of inertia of cross-sectional area $A^{i}$ of ith layer,

$k$ - curvature,

* - the convolution product,

$E^{i}$ - the relaxation function of material of of $i t h$ layer.

Unfortunately, the convolution product is a source of significant difficulties in calculations. Therefore, to calculate curvature $k$, deflections and normal stresses, an approximated calculation was used, where the convolution product is approximated by the sum with a variable summation limit [1], so representation (3.2) can be presented in the following form: 


$$
M\left(t_{m}\right)=\sum_{j=0}^{m}\left\{\left[\sum_{i=1}^{n} I^{i}\left(t_{m}\right) E^{i}\left(t_{m}-t_{j}\right)\right] \Delta k\left(t_{j}\right)\right\}
$$

and representation (3.3):

$$
\sigma^{i}\left(t_{m}\right)=\sum_{j=0}^{m} E^{i}\left(t_{m}-t_{j}\right) \cdot \Delta k\left(t_{j}\right) \cdot z^{i}\left(t_{m}\right)
$$

\section{RHEOLOGICAL MODEL}

The rheological properties of all materials are described with the five-parameter model shown in Fig. 4.

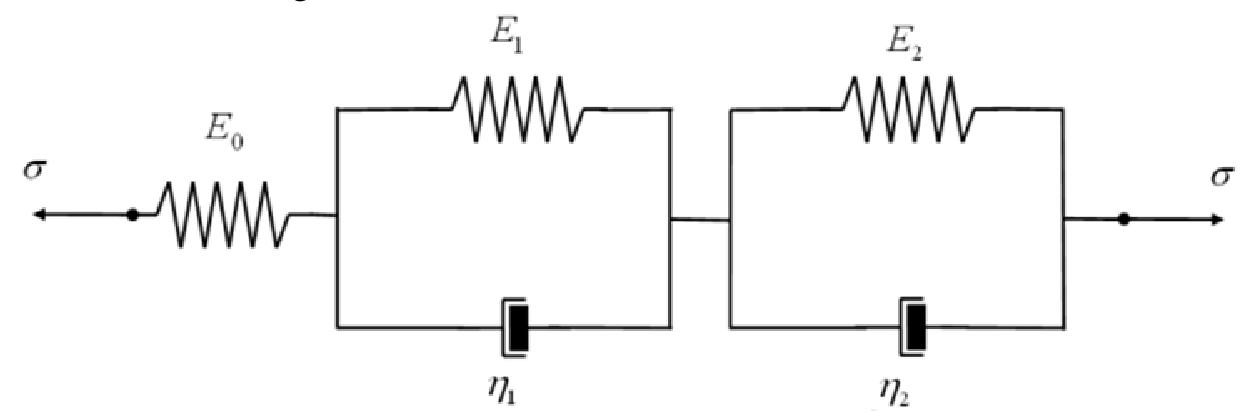

Fig. 4. Five-parameter rheological model

The mathematical formula for the relaxation modulus of this model was derived from the constitutive relations of linear viscoelasticity in differentia form by making use of the Laplace transformation $[1,3]$.

$$
\begin{gathered}
E(t)=\frac{1}{p_{2} \cdot \rho_{1} \cdot \rho_{2}} \cdot\left\{q_{0}-\frac{1}{\rho_{2}-\rho_{1}} \cdot\left[\rho_{2} \cdot e^{\rho_{1} \cdot t} \cdot\left(q_{0}+q_{1} \cdot \rho_{1}+q_{2} \cdot \rho_{1}^{2}\right)-\right.\right. \\
\left.\left.+\rho_{1} \cdot e^{\rho_{2} \cdot t} \cdot\left(q_{0}+q_{1} \cdot \rho_{2}+q_{2} \cdot \rho_{2}^{2}\right)\right]\right\}
\end{gathered}
$$

where:

$$
\rho_{1}=\frac{1}{2 \cdot p_{2}} \cdot\left[-p_{1}+\left(p_{1}^{2}-4 \cdot p_{2} \cdot p_{0}\right)^{\frac{1}{2}}\right]
$$




$$
\begin{gathered}
\rho_{2}=\frac{1}{2 \cdot p_{2}} \cdot\left[-p_{1}-\left(p_{1}^{2}-4 \cdot p_{2} \cdot p_{0}\right)^{\frac{1}{2}}\right] \\
p_{0}=E_{0} \cdot E_{2}+E_{1} \cdot E_{2}+E_{0} \cdot E_{1}, p_{1}=\left(E_{0}+E_{1}\right) \cdot \eta_{2}+\left(E_{2}+E_{0}\right) \cdot \eta_{1}, p_{2}=\eta_{1} \cdot \eta_{2} \\
q_{0}=E_{0} \cdot E_{1} \cdot E_{2}, q_{1}=E_{0} \cdot\left(E_{1} \cdot \eta_{2}+E_{2} \cdot \eta_{1}\right), q_{2}=E_{0} \cdot \eta_{1} \cdot \eta_{2}
\end{gathered}
$$

The model parameters $E$ and $\eta$ of these models have been determined from additional separate tests conducted on samples of these materials and evaluated by the method of least squares [3].

\section{NUMERICAL MODEL NO. 1}

Numerical model No. 1 based on the finite element method and a Lagrange functional written for the viscoelastic multi-layered beam and obtained by means of our own computer application, which was written in the environment of SCILAB. The multi-layered finite element (Fig. 5) described in [1] was used.

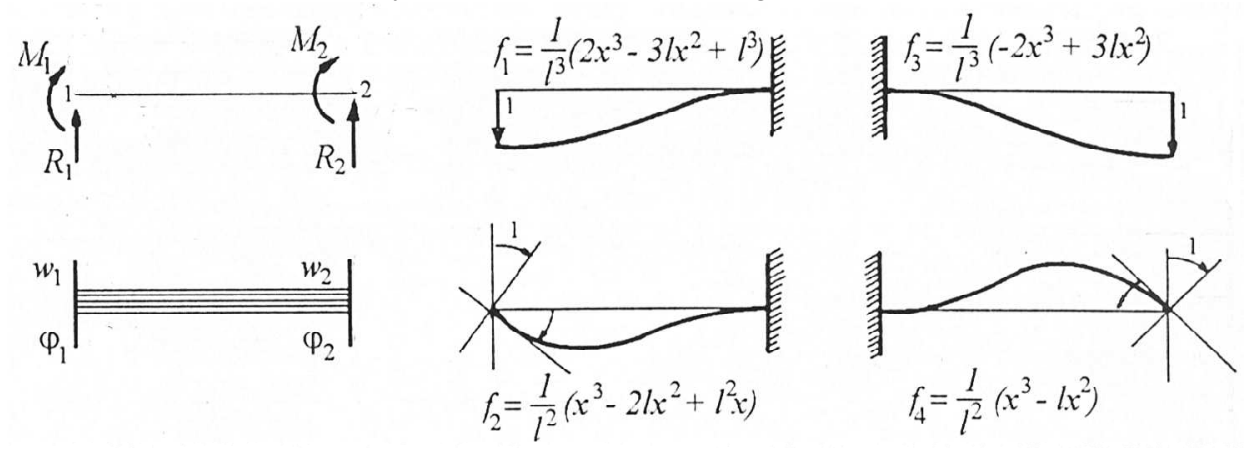

Fig. 5. The multi-layered finite element [1]

The numerical algorithm based on the FEM solves the integral equation of convolution type [1]:

$$
\mathbf{K} * \mathrm{~d} \mathbf{u}=\mathbf{R},
$$

where:

K - global stiffness matrix with entries changing in time,

u - vector of nodal displacements,

$\mathbf{R}$ - vector of nodal loads changing in time

The convolution product is approximated by the sum with a variable summation limit [1], so representation (5.1) can be presented in the following form: 


$$
\sum_{j=0}^{m}\left[\mathbf{K}\left(t_{m}-t_{j}\right) \cdot \Delta \mathbf{u}\left(t_{j}\right)\right]=\mathbf{R}\left(t_{m}\right)
$$

This algorithm is very time-consuming and ineffective.

\section{NUMERICAL MODEL NO. 2}

Numerical model No. 2 was made in ABAQUS and INTEL FORTRAN. The UMAT (User-defined MATerial) subroutine was used to implement the rheological model of component materials. This subroutine calculates the stress increment and the Jacobian matrix $\mathrm{C}$ of the constitutive model for each time increment [2]:

$$
\mathbf{C}=\frac{\delta \Delta \sigma}{\delta \Delta \varepsilon}
$$

Differential form of constitutive equations of five-parameter model and the central difference operator were used to calculate the Jacobian matrix [3]:

$$
p_{0} \cdot \sigma+p_{1} \cdot \dot{\sigma}+p_{2} \cdot \ddot{\sigma}=q_{0} \cdot \varepsilon+q_{1} \cdot \dot{\varepsilon}+q_{1} \cdot \ddot{\varepsilon} .
$$

All elements of reinforced beams (wood, glue, bars) were modeled as parts (PART) in ABAQUS. The parts (PART) were joined using TIE function. An element C3D8R (8-node linear brick, reduced integration with hourglass control) was used.

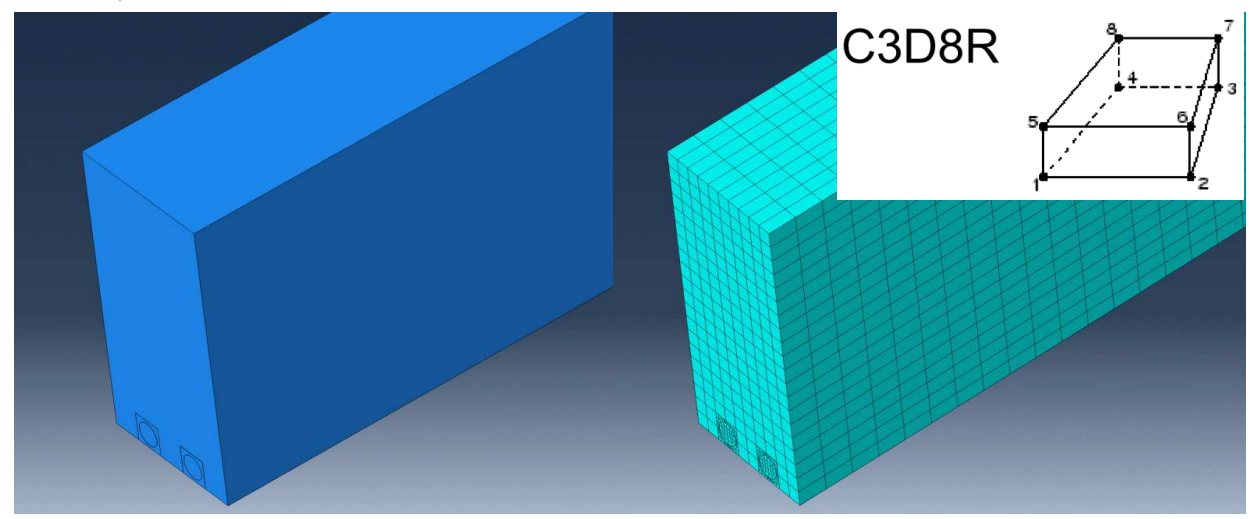

Fig. 6. Numerical model No. 2, ABAQUS 


\section{RESULTS}

The results of the calculations performed by means of equations (3.4), (3.5), (5.2) and ABAQUS in the form of experimental, theoretical and numerical deflections values, in selected days are presented in Fig. 7.

The experimental tests and numerical calculations confirm that the proposed models of the multi-layered beam can properly reflect the viscoelastic response of the analysed elements.

The analysis of correlation between theoretical and numerical deflection functions and mean values of experimental deflections was made using the deviation $s_{w o}$ :

$$
s_{w o}=\sqrt{\frac{1}{l} \cdot \sum_{k=1}^{l}\left(\frac{u_{t t}\left(x, t_{k}, E_{j}, \eta_{j}\right)-\bar{u}_{t d}\left(x, t_{k}\right)}{u_{t t}\left(x, t_{k}, E_{j}, \eta_{j}\right)}\right)^{2}} \cdot 100 \% .
$$

During all the period of time, strong linear interdependence was observed, $s_{w o}=0,955 \%$ for the theoretical model, $s_{w o}=0,587 \%$ for the numerical model No. $1, s_{w o}=0,868 \%$ for the numerical model No. 2 . The global shape of the curves is the same and the values are very close. Numerical model No. 1 is worse than No. 2. It is is very time-consuming and ineffective.

\section{CONCLUSIONS}

The experimental tests presented in the article and the theoretical elaboration of their results enable drawing the following conclusions:

1. A positive, but inconsiderable, influence of a polyester-glass composite reinforcement on rheological increments of deflections was stated. These increments are less than in case of non-reinforced beams.

2. The five-parameter rheological model describes rheology of applied materials very well.

3. The proposed theoretical and numerical models of reinforced beam displays good agreement with experimental data and can be used to calculate a broad range of settings, such as beams with glued-in reinforcement or the typical composite structures.

4. The numerical model No. 1 is very time-consuming and ineffective. 

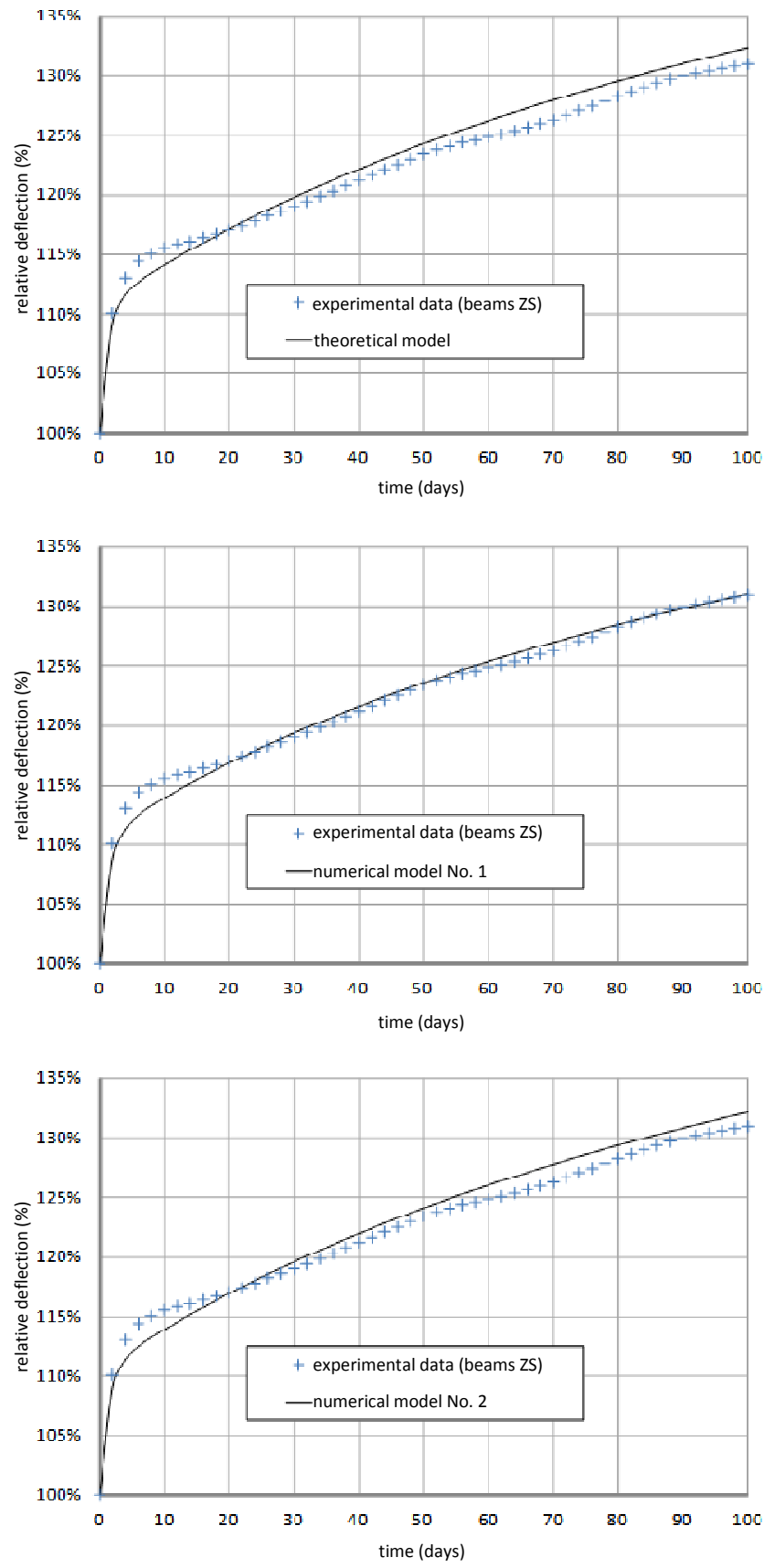

Fig. 7. Time-deflection experimental and numerical creep curves 


\section{REFERENCES}

1. Kubik J.: Mechanika konstrukcji warstwowych, Opole, TiT 1993.

2. Mirianon F., Fortino S., Toratti T.: A method to model wood by using ABAQUS finite element software, VTT Publications 687, VTT Technical Research Centre of Finland, 2008.

3. Socha T.: Ocena wptywu obciqżeń dtugotrwatych na naprężenia iodksztatcenia $w$ drewnianych belkach $z$ wklejonym zbrojeniem kompozytowym, Maszynopis rozprawy doktorskiej, Uniwersytet Zielonogórski 2005.

\section{NUMERYCZNA ANALIZA UGIĘĆ BELEK WARSTWOWYCH}

\section{Streszczenie}

$\mathrm{W}$ artykule przedstawiono problemy związane $\mathrm{z}$ reologicznymi przyrostami ugięć drewnianych belek $\mathrm{z}$ wklejonym wzmocnieniem kompozytowym. Zaprezentowano teoretyczny model pracy takiej belki jako układu warstwowego. Przyjęto hipotezę płaskich przekrojów i brak poślizgów między warstwami.Zachowania reologiczne materiałow składowych: drewna, kleju na bazie żywic epoksydowych i prętów z kompozytu poliestrowo-szklanego, opisano równaniami modelu pięcioparametrowego. Przygotowano dwa modele numeryczne. Do budowy modelu numerycznego $\mathrm{nr} 1$ wykorzystano wariacyjne ujęcie mechaniki prętowych układów warstwowych i metodę elementów skończonych. Otrzymane wyniki były zgodne z modelem analitycznym i danymi doświadczalnymi. Niestety zaproponowana metoda jest czasochłonna oraz wymaga dużej pamięci operacyjnej komputera. Model numeryczny nr 2 przygotowano w oparciu o system MES ABAQUS oraz samodzielnie napisaną w języku FORTRAN procedurę UMAT (User-defined MATerial) zawierającą zależności między naprężeniami a odkształceniami dla pięcioparametrowego modelu reologicznego. Uzyskano bardzo dużą zgodność z danymi doświadczalnymi i modelem analitycznym.

Słowa kluczowe: ABAQUS, drewno, kompozyty, konstrukcje warstwowe, MES, pełzanie, reologia, wzmacnianie

Editor received the manuscript: 2.12 .2014 